\title{
Student Interest of Music Career in Vocational School Yogyakarta Indonesia
}

\author{
H Y Wicaksono \\ \{herwin_yw@uny.ac.id\} \\ Universitas Negeri Yogyakarta, Yogyakarta, Indonesia
}

\begin{abstract}
The aim of this study is to highlighting the vocational school students' interest towards a career in music skills. The questions asked are as follows: What music careers are students interested in after graduating? Forty-five students were taken at $15 \%$ of the total population of 300 , determined by a purposive sampling technique. The data were collected by giving questionnaires about music careers, and analyzed by descriptive percentage. This study found that most of the interest of Vocational School Kasihan Bantul Yogyakarta Indonesia students towards a career in music expertise is in the field of music education. This is evidenced by $64.4 \%$ (29 students) choosing specialization as music educators, both at the school level and at the university level.
\end{abstract}

Keywords : Music Career, Vocational School, Yogyakarta Indonesia

\section{INTRODUCTION}

In essence, education is a process of fostering the existence of students who are social, cultured, in a way of life that has local, national, and global dimensions.(1). When talking about education in Indonesia, it cannot be separated from education figure Ki Hajar Dewantara. The concept of education according to Ki Hajar Dewantara (2) is a civilizing process that is an effort to give noble values to a new generation in society that is not only preservation, but also with the aim of advancing and developing culture towards the nobleness of life of humanity.

From this concept, it can be said that education facilitates the cultural transformation of human life both in one generation and between generations throughout the ages. Therefore, to achieve human life nobility, the generation needs to be equipped with education that is able to make them live independently, creatively, and have certain skills in their fields, so that these generations can improve the quality of their lives. One of education that can equip abilities and skills in a particular field is vocational education.

Vocational education is one type of education held in Indonesia at the secondary level which prepares students to enter employment. The success of vocational education can be measured from the level of absorption of graduates in the workforce, including graduates in the field of music expertise. Graduates in the field of music expertise can have professions such as music producers, music educators, music players, and makers of musical instruments. Of the several professions that graduates can have in the field of musical expertise, it can be said that graduates in the field of music expertise are not always music players. These graduates can even have broader careers.

However, based on a preliminary study conducted in November 2015, namely an interview with the head of Public Relations of SMK Negeri 2 Kasihan Bantul, it was known that the industrial work practices (prakerin) that had been done so far for students of class XI, in the 
form of musical performances held both in school and out of school. The internship process has been prepared for a period of one year, starting from the Welcome Concert to the concert tour to various agencies / institutions. With these conditions, students cannot choose another career in the music field.

Looking at the implementation of the apprenticeship, it can be said that graduates produced from SMK Negeri 2 Kasihan Bantul are almost all prepared to become music players. This is also seen based on the curriculum used. In fact, graduates from SMK Negeri 2 Kasihan Bantul can be prepared to have a wider profession (in the same field), such as music instrument makers/designers, music educators, executive music directors, restoration specialists and repairs to musical instruments, librarian music, and stage managers . These professions can be used as alternatives for students who lack musicality and lack skills in playing musical instruments.

Based on this, the school can facilitate and develop a wider pattern of internship in the music field. That is, the implementation of the apprenticeship held by SMK Negeri 2 Kasihan Bantul, is no longer just in the form of performances, but also can be apprenticed in places such as making musical instruments, music studios and concert halls. Therefore, the school can establish cooperation and partnerships with the industrial world in these places. With the broader implementation of internship held by the school, students can choose and determine their career in the music field in accordance with the desired interest.

This profession / career in the field of musical expertise can be a provision for students to improve the quality of life. This is because, by having such a profession, graduates of this music school can create a workforce independently. Even this profession can be a stock of skills in the face of the Asean economic community (MEA) which was just announced by the Indonesian government on January 1, 2016. With the MEA in this era, schools (SMK Negeri 2 Kasihan Bantul) can develop the implementation of internship, so that the graduates can work not only as players, but also have careers as music producers, piano tuners, music educators, and makers / designers. musical instruments. With the choice of career prepared, the graduates of the school can also compete with professionals from other Asean countries.

\section{RESEARCH METHOD}

This type of survey is one type of quantitative research used in this study, because it will get a large set of information about the population related to career interest in the field of expertise of students of SMK Negeri 2 Kasihan Bantul who became the research sample using a questionnaire. That is, the numbers and opinions of a population by examining the population sample and using the questionnaire as a basic data collection tool will be described quantitatively (3). The same thing was also stated by Sukmadinata (2008: 82) who said survey research was used to collect data or information about large populations using relatively small samples. Therefore, survey research is used in this study to examine the cases that want to be explained precisely by obtaining information on student career interests in the field of musical expertise using a questionnaire.

Questionnaires were given to 45 students as research samples. This sample is determined by $15 \%$ of the population, which is 300 students, and determined by purposive sampling. Determined the number of samples, because the population is quite large, so it is taken 
between $10-15 \%$ (4). The data have been collected, then analyzed using a percentage formula as follows (5).

$$
P=\frac{F}{N} \times 100 \%
$$

\section{RESULTS AND DISCUSSION}

Results

The SPSS statistics program offers a wealth of possibilities for statistical analysis. With the help of SPSS, the percentage of each career that students are interested in is known. The percentage amount potentially describes the number of students towards a particular career in the music. The complete results of this study are shown in Table 1.

Table 1. Percentage of career interest in the field of music expertise students of SMK Negeri 2 Kasihan Bantul

\begin{tabular}{|l|c|c|}
\hline \multicolumn{1}{|c|}{$\begin{array}{c}\text { Type of } \\
\text { Career in the Field of } \\
\text { Music }\end{array}$} & The number of students & Percentage \\
\hline Music educator & 29 & 64,4 \\
\hline $\begin{array}{l}\text { Repairer and designer } \\
\text { of musical instruments }\end{array}$ & 8 & 17,7 \\
\hline $\begin{array}{l}\text { Symphony and } \\
\text { Orchestra }\end{array}$ & 3 & 6,66 \\
\hline $\begin{array}{l}\text { Facilities and Concert } \\
\text { Hall }\end{array}$ & 5 & 11,1 \\
\hline
\end{tabular}

In table 1, it appears that careers in the field of music expertise that are in great demand by students are music educators both at the university level and at the middle level, amounting to 29 students $(64.4 \%)$. The second highest interest in careers in the field of music expertise is the improvement and design of musical instruments as many as 8 students (17.7\%). Furthermore, followed by specialization of careers in the field of symphony and orchestra, namely as many as 5 students (11.1\%). The smallest specialization in the field of music expertise career chosen by students is in the field of facilities and concert halls, as many as 3 students $(6.66 \%)$. The results of these studies indicate that many students are interested in becoming educators in the field of musical expertise. This was also supported by the results of interviews with several students conducted on August 11, 2016. These data if arranged in a pie chart can be seen in Figure 1. 


\section{Specialization Music Career Expertise}

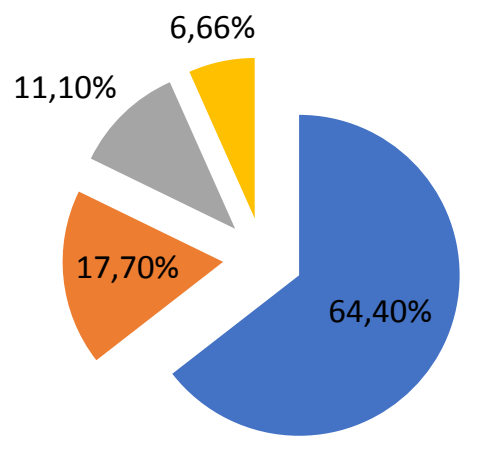

Pendidik

Perbaikan dan instrumen

musik

Simfoni dan Orkestra

Fasilitas dan concert hall

Figure 1. Data on specialization in the field of music expertise in pie charts

From Figure 1, it can be explained that most students at SMK Negeri 2 Kasihan Bantul $(64.4 \%)$ are interested in becoming an music educator. This means that the school can collaborate with school parties to provide opportunities for students who are guided to try to practice teaching music.

\subsection{Discussion}

SMK Negeri 2 Kasihan Bantul is one of the vocational schools that organizes the learning process in the field of music expertise, especially Western art music. Thus, of course the graduates they produce are also prepared to work in these fields of expertise.

As a vocational school, the school provides knowledge and expertise in the field of music. One of the subjects given to students is industrial work practices (internship). This is given so that students can gain experience as the real world of work.

Based on the preliminary study described in the background, it is known that the apprenticeship carried out at SMK Negeri 2 Kasihan Bantul has been in the form of staging music in orchestral formats in schools both junior high and high school. It shows as if students are prepared only as music players. Even though not all students in the school want to become music players. In fact, it does not rule out the possibility that there are students who have a level of musicality that is not too good, so that a container that provides experience for these students is needed [7].

This condition has been proven based on the results of research that has been conducted, where most of the students of SMK Negeri 2 Kasihan Bantul, are interested in having a career in music educators, and some are interested in the field of music expertise in Symphony \& Orchestra, repair and designer of musical instruments, and work at the concert hall associated with music facilities. With the results of these studies, the school can establish cooperation with the related industries to provide work experience provisions that are really in demand by students. 


\section{CONCLUSIONS}

Based on the results of the research that has been obtained, it can be concluded that of the 45 students who became the study sample, it was found that 29 students $(64.4 \%)$ chose careers in the field of music educators both at the university level and at the secondary level; 8 students $(17.7 \%)$ chose career interests in the field of repair and design of musical instruments; 5 students $(11.1 \%)$ chose career interests in the fields of symphony and orchestra; and 3 students $(6.66 \%)$ chose careers in facilities and Concert Hall. Thus, it can be said that basically the students who take the learning at SMK Negeri 2 Kasihan Bantul do not all want to become music players, but also there are students who are interested in choosing careers as music educators, and as music instrument designers and technicians.

\section{REFERENCES}

[1] Mudyaharjo, R. Pengantar Pendidikan Sebuah Studi Awal Tentang Dasar-Dasar Pendidikan Pada Umumnya Dan Pendidikan Di Indonesia. Jakarta: Raja Grafindo Persada. Jakarta: 2013

[2] A Adytias. Pendidikan Sebagai Proses Pembudayaan: Padangan Ki Hajar Dewantara. Diunduh 10 Januari 2015, dari http://zahratyas.blogspot.co.id/2013/04/pendidikansebagai-proses-pembudayaan.html. 2013.

[3] Creswell, J.W. Research Design: Qualitative, Quantitative, And Mixed Methods Approaches. Diterjemahkan oleh Achmad Fawaid. Yogyakarta: Pustaka Pelajar. Yogyakarta: 2010.

[4] Suharsimi, A. Prosedur Penelitian : Suatu Pendekatan Praktis, edisi revisi 2010. Jakarta : Rineka Cipta. Jakarta: 2010.

[5] Sudjana, N. Metode Statistika Edisi ke-6. Bandung : Tarsito. Bandung: 2005.

[6] Sukmadinata, N. S. (2008). Kurikulum dan pembelajaran kompetensi. Bandung: Yayasan Kusumakarya. Bandung: 2008

[7] A.J. Harahap, E. Ongko, H. Manurung, D. Kurnia, H. Hartono, D. Abdullah, K. Saddhono, and C.I Erliana "Sylabus and Matrials Design for Vocational Student and Its Dissemination Using Website." In IOP Journal of Physics: Conference Series, vol. 1114 no. 1, p. 012023. IOP Publishing, 2018. 